\title{
Association and Path Coefficient Studies for Traits Related to Water Use Efficiency, Yield and Its Components in RILs of Groundnut (Arachis hypogaea L.)
}

\author{
A. Anusha Hugar ${ }^{1,2^{*}}$ and D.L. Savithramma ${ }^{1}$ \\ ${ }^{1}$ University of agricultural sciences, Bengaluru, Karnataka- 560065, India \\ ${ }^{2}$ University of Agriculture Science, Raichur, Karnataka-584101, India \\ *Corresponding author
}

\begin{tabular}{|c|c|}
\hline & A B S T R A C T \\
\hline Keywords & \multirow{8}{*}{$\begin{array}{l}\text { The extent of association between pod yield and other relevant traits was } \\
\text { estimated in the RILs of groundnut. Significant positive association of pod } \\
\text { yield per plant with primary branches per plant, SCMR, pods per plant and } \\
\text { kernel yield per plant was observed. Also significant negative association } \\
\text { of pod yield per plant with SLA and sound mature kernel per cent was } \\
\text { noticed. The physiological traits related to Water Use Efficiency, SLA and } \\
\text { SCMR were negatively associated to each other with the latter being } \\
\text { associated positively and the former associated negatively with pod yield. } \\
\text { Pods per plant, kernel yield and primary branches per plant also had } \\
\text { positive direct effect indicating that the correlation between these } \\
\text { characters with pod yield is due to direct effect of the characters and reveals } \\
\text { the true relationship between them. }\end{array}$} \\
\hline $\begin{array}{l}\text { Groundnut, Recombinant } \\
\text { Inbred Lines (RILs), }\end{array}$ & \\
\hline $\begin{array}{l}\text { Water use efficiency } \\
\text { (WUE), Soil Plant }\end{array}$ & \\
\hline $\begin{array}{l}\text { WUE), Soil Plant } \\
\text { Analysis Development } \\
\text { (SPAD). Chlorophyll }\end{array}$ & \\
\hline $\begin{array}{l}\text { Meter Reading, Specific } \\
\text { Leaf Area (SLA). }\end{array}$ & \\
\hline $\begin{array}{l}\text { Correlation and Path } \\
\text { analysis. }\end{array}$ & \\
\hline Article Info & \\
\hline $\begin{array}{l}\text { Accepted: } \\
\text { 17 July } 2017 \\
\text { Available Online: } \\
\text { 10 September } 2017\end{array}$ & \\
\hline
\end{tabular}

\section{Introduction}

India is now facing a water situation that is significantly worse than any of those previous generations have had to face. All Indian water bodies within and near population centres are now grossly polluted with organic and hazardous pollutants.

By 2030 nearly $60 \%$ of Indian aquifers will be in a critical condition thus posing a threat to agriculture (Biswas et al., 2017). Hence it becomes necessary to breed crops with higher water use efficiency for sustenance.
Peanut addressed as one of the world's most important legumes both in subsistence and commercial agriculture holding a good stand both in arid and semi-arid regions of the world also suffers from lower water availability.

Thus development of peanut cultivars with resistance to drought and more efficient use of water offer the best long term and cost effective solution to the drought problem. One such approach includes physiological 
estimation and evaluation of genotypes. However, physiological traits associated with drought tolerance are complex as well as difficulties associated with their measurements in segregating populations inhibited their use in the past in developing water-use efficient genotypes in breeding programmes. With new knowledge of easily measurable surrogates of transpiration efficiency (TE), a trait which is associated with drought tolerance like specific leaf area (SLA) and soil plant analytical development (SPAD) chlorophyll meter reading (SCMR), it is now possible to integrate TE through the surrogates in breeding and selection schemes in groundnut.

So far many studies on the surrogate traits for WUE in peanut have been focused on SLA and SCMR. A strong and positive relationship between SCMR and WUE was reported (Sheshshayee et al., 2006). SCMR and SLA are negatively correlated (Nageswara Rao et al., 2001; Upadhyaya, 2005) and genetic variation for SCMR has also been reported (Upadhyaya, 2005).

Most of the characters of breeder's interest are complex and are the result of interaction of a number of components. Understanding the relationships among yield and yield components is of paramount importance for making the best use of these relationships in selection. The correlation coefficient may be confounded with indirect effect due to common association inherent in trait interrelationships. Therefore information derived from the correlation coefficients can be augmented by partitioning correlations into direct and indirect effects by path coefficient analysis.

\section{Materials and Methods}

The experiment was carried out in the interim of kharif 2014-2015 at GKVK, Bangalore.
Experimental material consisted of mapping population of 230 RILs of cross NRCG 12568 $\times$ NRCG 12326 (Table 1) segregating for Water Use Efficiency and the checks included TMV-2 and KCG-2 genotypes. The $230 \mathrm{~F}_{7}$ generation RILs were sown in augmented design with 4 checks including parents during kharif 2014 for phenotypic evaluation. Each RIL sown in a single row of $1.5 \mathrm{~m}$ with a spacing of $30 \mathrm{~cm}$ between rows and $10 \mathrm{~cm}$ between plants within the row. Recommended fertilization application and agronomic practices as per the package of practices mentioned for this region were followed. Data were recorded on randomly selected five plants from each RIL and average value was used for the statistical analysis for 10 characters viz., days to $50 \%$ flowering, plant height $(\mathrm{cm})$, number of primary branches per plant, number of mature pods per plant, pod yield per plant $(\mathrm{g})$, sound mature kernel (SMK) percentage, kernel yield per plant (g), shelling percentage, SPAD chlorophyll meter reading and specific leaf area $\left(\mathrm{cm}^{2} / \mathrm{g}\right)$.

Observations of above quantitative traits were recorded in $\mathrm{F}_{7}$ generation and were subjected to statistical analysis (Sapra and Agarwal, 1991). Further the data was analysed using WINDOSTAT for augmented design.

\section{Results and Discussion}

Pod yield is a complex character which is governed by several contributing traits. Hence, it necessitates understanding the association of different traits with pod yield for enhancing the usefulness of selection criterion to be followed while developing varieties.

The study revealed that there is a strong positive association between pod yield per plant with traits such as primary branches per plant, SCMR, pods per plant and kernel yield per plant and strong negative association with 
SLA and sound mature kernel per cent (Table 2). It suggests that the individual plant selection can be practiced for plants with higher number of primary branches and higher number of pods which ultimately leads to improvement in both pod and kernel yield in the later generations. It also suggests that plants with higher SCMR and lower SLA can be selected to choose plants with high water use efficiency coupled with higher yield.

The significant positive association of pod yield per plant with pods per plant and kernel yield per plant in the RILs are in accordance with the results of Sharma and Varshney (1995), Moinuddin (1997), Singh and Singh (1999), Nagda et al., (2001), Kalmeshwar et al., (2006), John et al., (2007), Mane et al., (2008) and Sudhir et al., (2008) suggesting that pod yield can be improved by selecting plants with higher pods per plant and higher kernel yield.

Strong positive association of primary branches per plant with pod yield per plant indicates by selecting for higher number of primary branches improvement in yield can be achieved similar to the results of Vasanthi et al., (2015), Chandola et al., (1973), Prasad (1981), Balkishan (1979), Bhargava et al., (1970), Khangura and Sandhu (1972), Sandhu and Khera (1977).

SCMR witnessed a significant positive association with pod yield per plant and same was reported by Pavan et al., in 2014, indicating that this association can be utilized to select high yielding plants by selecting those plants scoring higher for SCMR values.
Significant negative association of pod yield per plant with SLA suggests that selection of plants with lower SLA leads to selection of plants with high water use efficiency coupled with higher pod yield per plant similar to the results of Nandini and Savithramma in 2012. A significant positive association of SCMR and significant negative association of SLA with pod yield per plant imply that selecting genotypes having lower SLA coupled with higher SCMR values implies higher water use efficiency along with higher pod yield per plant.

Though correlation coefficient measures the relationship existing between pairs of characters, dependent character is an interaction product of many mutually associated component characters and change in any one component will disturb whole network of cause and effect system this is taken care by path coefficient analysis which takes into account both the cause and effect relation between the variables.

The path coefficient analysis also measures the relative importance of causal factors involved. It is simply a standardized partial regression co-efficient analysis that separates the correlation co-efficient into components of direct and indirect effects and measures the relative importance of each factor involved in contributing to the final product of correlation between dependent and independent characters.

It reflects the association between them. Selection for such characters will be rewarding to improve dependent characters.

Table.1 Salient features of parental genotypes

\begin{tabular}{|l|l|l|l|l|}
\hline Parental Genotypes & Varietal type & 13C & SLA(cm2/g) & SCMR \\
\hline NRCG 12568 & Fastigiata & 16.90 & Low & High \\
\hline NRCG 12326 & Vulgaris & 21.50 & High & Low \\
\hline
\end{tabular}


Table.2 Estimates of phenotypic correlation coefficients among growth, yield and surrogate traits related to WUE of $230 \mathrm{~F}_{7} \mathrm{RILs}_{\mathrm{W}}$ the cross NRCG $12568 \times$ NRCG 12326 in groundnut

\begin{tabular}{|c|c|c|c|c|c|c|c|c|c|c|}
\hline & $X_{1}$ & $X_{2}$ & $X_{3}$ & $X_{4}$ & $X_{5}$ & $X_{6}$ & $X_{7}$ & $\mathrm{X}_{8}$ & $X_{9}$ & $X_{10}$ \\
\hline $\mathrm{X}_{1}$ & 1.000 & 0.048 & 0.049 & 0.012 & -0.014 & -0.028 & -0.124 & -0.107 & $0.211^{* *}$ & -0.113 \\
\hline $\mathrm{X}_{2}$ & & 1.000 & -0.065 & -0.045 & -0.101 & 0.048 & 0.019 & -0.089 & -0.068 & 0.026 \\
\hline$X_{3}$ & & & 1.000 & $0.134 *$ & -0.032 & 0.062 & $0.147 *$ & -0.078 & 0.023 & $0.165^{*}$ \\
\hline $\mathrm{X}_{4}$ & & & & 1.000 & $-0.351 * *$ & $0.327 * *$ & $0.326 * *$ & -0.047 & -0.082 & $0.296 * *$ \\
\hline $\mathrm{X}_{5}$ & & & & & 1.000 & -0.094 & $-0.315 * *$ & 0.0532 & 0.121 & $-0.302 * *$ \\
\hline $\mathrm{X}_{6}$ & & & & & & 1.000 & $0.514 * *$ & -0.009 & $-0.131 *$ & $0.550 * *$ \\
\hline $\mathrm{X}_{7}$ & & & & & & & 1.000 & -0.003 & $-0.186 * *$ & $0.879 * *$ \\
\hline $\mathrm{X}_{8}$ & & & & & & & & 1.000 & $-0.156^{*}$ & -0.118 \\
\hline $\mathrm{X}_{9}$ & & & & & & & & & 1.000 & $-0.203 * *$ \\
\hline $\mathrm{X}_{10}$ & & & & & & & & & & 1.000 \\
\hline
\end{tabular}

* Significant at 0.05 probability level

** Significant at 0.01 probability level
$\mathrm{X}_{1}$ : Days to $50 \%$ flowering
$\mathrm{X}_{2}$ : Plant height $(\mathrm{cm})$
$\mathrm{X}_{7}$ : Kernel yield/plant $(\mathrm{g})$
$\mathrm{X}_{3}$ : Primary branches/plant
$\mathrm{X}_{4}: \operatorname{SCMR}$
$\mathrm{X}_{9} \cdot \operatorname{SMK}(\%)$
$\mathrm{X}_{5}: \operatorname{SLA}\left(\mathrm{cm}^{2} / \mathrm{g}\right)$
$\mathrm{X}_{10}$. Pod yield/plant $(\mathrm{g})$

Table.3 Estimates of direct and indirect effects of yield components and surrogate traits related to WUE on pod yield in $230 \mathrm{~F}_{7}$ RILs of the cross NRCG12568 $\times$ NRCG12326 in groundnut

\begin{tabular}{|c|c|c|c|c|c|c|c|}
\hline & $\mathbf{X}_{\mathbf{1}}$ & $\mathbf{X}_{\mathbf{2}}$ & $\mathbf{X}_{\mathbf{3}}$ & $\mathbf{X}_{\mathbf{4}}$ & $\mathbf{X}_{\mathbf{5}}$ & $\mathbf{X}_{\mathbf{6}}$ & "r" (Pod yield / plant) \\
\hline $\mathrm{X}_{1}$ & $\mathbf{0 . 1 4 4 4}$ & 0.0089 & 0.0473 & -0.0136 & 0.0743 & -0.0189 & $0.5505^{* *}$ \\
\hline $\mathrm{X}_{2}$ & 0.0028 & $\mathbf{0 . 0 4 4 6}$ & 0.0060 & -0.0014 & 0.0066 & 0.0010 & $0.1655^{*}$ \\
\hline $\mathrm{X}_{3}$ & -0.0111 & -0.0046 & $\mathbf{- 0 . 0 3 4 0}$ & 0.0119 & -0.0111 & 0.0028 & $0.2956^{* *}$ \\
\hline $\mathrm{X}_{4}$ & 0.0044 & 0.0015 & 0.0163 & $\mathbf{- 0 . 0 4 6 4}$ & 0.0146 & -0.0056 & $-0.3025^{* *}$ \\
\hline $\mathrm{X}_{5}$ & 0.4053 & 0.1158 & 0.2571 & -0.2485 & $\mathbf{0 . 7 8 8 2}$ & -0.1465 & $0.8793^{* *}$ \\
\hline $\mathrm{X}_{6}$ & 0.0047 & -0.0008 & 0.0030 & -0.0044 & 0.0067 & $\mathbf{- 0 . 0 3 6 3}$ & $-0.2035^{* *}$ \\
\hline
\end{tabular}

$\mathrm{X}_{1}$ : Pods/plant $\mathrm{X}_{2}$ : Primary branches/plant $\quad \mathrm{X}_{3}$ : SCMR $\quad \mathrm{X}_{4}$ : SLA $\left(\mathrm{cm}^{2} / \mathrm{g}\right) \mathrm{X}_{5}$ : Kernel yield/plant $(\mathrm{g}) \mathrm{X}_{6}:$ SMK $(\%)$ 
Maximum positive direct effect of kernel yield on pod yield per plant was observed suggesting selection for kernel yield would contribute greatly towards enhancing pod yield per plant (Table 3 ).

These results are in accordance with the reports of Abraham (1990), Moinuddin (1997), Gomes et al., (2005), Kalmeshwar et al., (2006), Praveen Kumar (2006) and Kumar et al., (2012) in groundnut.

Other traits such as pod per plant and primary branches per plant also had positive direct effect.

It reveals that the correlation between these characters and pod yield is due to direct effect of the characters such as primary branches per plant, kernel yield and pod per plant and it reveals the true relationship between the these characters with pod yield.

Hence selection for higher primary branches per plant, kernel yield and pod per plant will forthwith increases the pod yield.

So, as a concluding remark, by practicing simultaneous selection with higher number of primary branches per plant, pods per plant, higher kernel yield, higher values of SCMR and lower estimates of SLA, genotypes with both high water use efficiency and higher yield can be achieved.

\section{References}

Abraham, M. J., 1990, Correlation, Path and discriminant function analysis in Groundnut grown on $\mathrm{P}$ deficient acidic soil. Crop Improv., 17(1): $34-37$.

Balkishan, P., 1979, Studies on the genetic parameters in the F2 generation of eight crosses of groundnut (Arachis hypogaea L.). M. Sc. thesis, Andhra Pradesh Agricultural University, Hyderabad, Andhra Pradesh, India. pp. 91.
Bhargava, P.D., Dixit, P. K., Saxena, D. K. and Bhatia, L. K. 1970, Correlation studies on yield and its components in erect varieties of groundnut (Arachis hypogaea L.). Rajasthan J. Agri. Sci., 1: 64-71.

Biswas, A.K., Tortajada C. and Saklani U. (2017), Pumped dry: India's accelerating and invisible ground water crisis. Policy Forum, Asia and the Pacific's platform for public policy analysis and opinion (Online). Available: https://www.policyforum.net/pumpeddry/html [Accessed on 16.07.2017].

Chandola, R.P., Dixit, P. K. and Saxana, D. K., 1973, Note on path coefficient analysis of yield components in groundnut. Ind. $J$. Agri. Sci., 43: 897-898.

Gomes, R.L., and Lopes, A., 2005, Correlation and path analysis in Peanut. Crop Breed. Appl. Biotech., 5(1): 105-110

John, K., Vasanthi, R. P. and Venkateswarlu, O., 2007, Variability and correlation studies for pod yield and its attributes in F2 generation of six Virginia $x$ Spanish crosses of groundnut (Arachis hypogaea L.). Leg Res. 30(4): 292-296

Kalmeshwar, G.P., Kenchangoudar, P. V., Parmeshwarappa, K. G. and Salimath, P. M., 2006, A study of correlation and path analysis in groundnut. Karnataka J. Agric. Sci., 19: 272-277.

Kameshwara, R.K., Burow, M. D., Burow, G., Burke, J. and Puppala, N., 2007, Molecular characterization of the U.S. Peanut Mini Core collection using Microsatellite Markers. Crop Sci., 47: 1718-1727.

Khangura, J.L., and Sandhu, R. S., 1972, Path analysis in groundnut (Arachis hypogaea L.). Ind. J. Agri. Sci. 42: 792-795.

Kumar, D.R., Reddi Sekhar, M., Raja Reddy. K. and Ismail. S., 2012, Character association and path analysis in groundnut (Arachis hypogaea L.). Int. J. App. Bio. Pharma. Tech., 3(1): 385-389.

Mane, P.S., Lad, D. B. and Jagtap, P. K., 2008, Correlation and path coefficient analysis in summer bunch groundnut. J. Maharastra. Agri. Univ. 33(2): 174-176

Moinuddin, H.H., 1997, Evaluation of Genotype x Environment interaction in Groundnut (Arachis hypogaea L.) genotypes. M.Sc. 
(Agri) thesis submitted to University of Agricultural Sciences, Bangalore

Nagda, A.K., Dashora, A. and Jain, D. K., 2001, Character association in parents and hybrids of groundnut (Arachis hypogaea L.). Crop Res., 22(3): 463-468.

Nageswara Rao, R.C., Talwar, H. S. and Wright, G. C., 2001, Rapid assessment of specific leaf area and leaf nitrogen in peanut (Arachis hypogaea L.) using a chlorophyll meter. J. Agron. Crop. Sci., 186: 175-182.

Pavan Kumar, C., Rekha, R., Venkateswarulu, O. and Vasanthi, R. P., 2014, Correlation and path coefficient analysis in Groundnut (Arachis hypogaea L.). Inter. J. Applied. Bio. Phar.Tech., 5(1): 8-11.

Prasad, M. K. D., 1981. Genetic characterization and heterotic potential of varietal groups i $\mathrm{n}$ groundnut (Arachis hypogaea L.). Ph.D thesis, Andhra Pradesh Agricultural University, Hyderabad, Andhra Pradesh, India. 303 pp.

Praveen Kumar, P., 2006, Genetics of Water Use Efficiency (WUE), yield and its related traits in groundnut. (Arachis hypogaea L.). M.Sc. (Agri) thesis submitted to the University of Agricultural sciences, Bangalore.

Sandhu, B.S., and Khera, A. S., 1977, Interrelationships on semi-spreading $\mathrm{x}$ bunch and semi-spreading $\mathrm{x}$ semi-spreading crosses of groundnut. Ind. J. Gen. Pl. Breed., 37: 22-26.

Sapra, R.L., and Agarwal, R. C., 1991,
Germplasm evaluation; Augmented design. In; Plant Genetic Resources; Documentation and Information management, NBPGR, New Delhi, pp 37 44

Sharma, V.K., and Varshney, S. K., 1995, Analysis of harvest index in groundnut. J.Oilseeds Res., 12(2): 171-175

Sheshshayee, M.S., Bindumadhava, M., Rachaputi, N. R., Prasad, T. G., Udaykumar, M., Wright, G. C. and Nigam, S. N., 2006, Leaf chlorophyll concentration relates to transpiration efficiency in peanut. Annals Appl. Biol., 148: 7-15.

Singh, S.B., and Singh, J. P., 1999, Correlation analysis of growth and yield components in groundnut. J. Maharashtra Agric. Univ., 24(1): 48- 49.

Sudhir, K.J., Venkataravana and Guraraj Rao., 2008, Evaluation of new germplasm and advanced breeding lines of groundnut (Arachis hypogaea L.) under late Kharif situation. Legume Res., 31(4): 254-258.

Upadhyaya, H.D., 2005, Variability for drought resistance related traits in the mini core collection of peanut. Crop Sci., 45: 14321440

Vasanthi, R.P., Suneetha, N. and Sudhakar, P., 2015, Genetic variability and correlation studies for morphological, yield and yield attributes in groundnut (Arachis hypogaea L.). Legume Research, 38(1): 9-15.

\section{How to cite this article:}

Anusha Hugar, A. and Savithramma, D. L. 2017. Association and Path Coefficient Studies for Traits Related to Water Use Efficiency, Yield and Its Components of RILs in Groundnut (Arachis hypogaea L.). Int.J.Curr.Microbiol.App.Sci. 6(9): 1266-1271. doi: https://doi.org/10.20546/ijcmas.2017.609.152 